\title{
Antibody-drug Conjugate ABBV-176
}

National Cancer Institute

\section{Source}

National Cancer Institute. Antibody-drug Conjugate ABBV-176. NCI Thesaurus. Code C137991.

An antibody-drug conjug ate (ADC) composed of a proprietary monoclonal antibody against the prolactin receptor (PRLR) linked to an as of yet undisclosed cytotoxic agent, with potential antineoplastic activity. Upon intravenous administration, the monoclonal antibody moiety of ABBV-176 targets and binds to PRLR expressed on tumor cells. Upon binding and internalization, the cytotoxic agent is released and kills the PRLR-expressing tumor cells, through an as of yet unknown mechanism of action. PRLR, a tumorassociated antigen (TAA), is overexpressed by a variety of tumor cell types. 